\title{
Tracking atmospheric dispersion of metals in Rio de Janeiro Metropolitan region (Brazil) with epiphytes as bioindicators
}

\author{
AGUINALDO N. MARQUES JUNIOR ${ }^{1}$, DOUGLAS P. PANETTO ${ }^{1}$, FERNANDO LAMEGO ${ }^{1,2}$, FELIPE \\ O. NEPOMUCENO ${ }^{3}$, FABRICE MONNA ${ }^{4}$, REMI LOSNO ${ }^{5}$ and RODRIGUE GUILLON ${ }^{4}$ \\ ${ }^{1}$ Programa de Pós-Graduação em Biologia Marinha e Ambientes Costeiros, Departamento de Biologia Marinha, Instituto \\ de Biologia, Universidade Federal Fluminense, Outeiro São João Batista, s/n, Centro, 24001-970 Niterói, RJ, Brazil \\ ${ }^{2}$ Comissão Nacional de Energia Nuclear/CNEN, Instituto de Engenharia Nuclear/IEN, Rua \\ Hélio de Almeida, 75, Ilha do Fundão, 21941-906 Rio de Janeiro, RJ, Brazil \\ ${ }^{3}$ Departamento de Geologia, Instituto de Geociências, Universidade Federal do Rio de Janeiro, Avenida \\ Athos da Silveira Ramos, 274, Ilha do Fundão, 21941-916 Rio de Janeiro, RJ, Brazil \\ ${ }^{4}$ UMR 6298 CNRS-Université Bourgogne Franche-Comté, Archéologie, Terre, Histoire, Sociétés, \\ Bâtiment Sciences Gabriel/ARTEHIS, 6, Boulevard Gabriel, 21000 Dijon, France \\ ${ }^{5}$ Institut de Physique du Globe de Paris/IPGP, Université Paris Diderot, Sorbonne \\ Paris Cité, UMR CNRS 7154, 1 rue Jussieu,75013 Paris, France
}

Manuscript received on November 16, 2017; accepted for publication on April 4, 2018

\begin{abstract}
The atmospheric dispersion atmospheric plume of the metropolitan region and neighborhoods of the city of Rio de Janeiro was investigated through elemental analyzes ( $\mathrm{Na}, \mathrm{K}, \mathrm{Al}, \mathrm{Mn}, \mathrm{Pb}, \mathrm{Ni}, \mathrm{Cr}$ ) and stable lead isotopes in two epiphytes; the lichen Parmotrema crinitum (Ach.) and the bromeliad Tillandsia usneoides (L.). All the elements had lower concentrations in epiphytes than in rocks of the local geological basement, with the exception of $\mathrm{K}$, which was similar to rocks. This behavior was attributed to the nutritional essentiality and abundance of this element in the environment. The concentrations of $\mathrm{Na}, \mathrm{Pb}$ and the ${ }^{206} \mathrm{~Pb} /{ }^{207} \mathrm{~Pb}$ and ${ }^{208} \mathrm{~Pb} /{ }^{206} \mathrm{~Pb}$ ratios indicated the presence of spatial gradients in the path (a) sea shore $\rightarrow$ continent, and (b) urban center $\rightarrow$ farmlands. These patterns were associated with the mesoscale atmospheric circulation regime, in which, during the arrival of cold fronts, air masses from the metropolitan region of Rio de Janeiro are transported towards the mountainous region of Teresópolis, which acts as a barrier to the dispersion of pollutants. The bromeliad Tillandsia usneoides and the lichen Parmotrema crinitum were linked to $\mathrm{Na}$ and $\mathrm{Pb}$ atmospheric levels, respectively.
\end{abstract}

Key words: Stable lead isotopes, atmospheric pollution, Parmotrema crinitum (Ach.), Tillandsia usneoides (L.)

\section{INTRODUCTION}

The air quality of urban centers is affected by a range of substances, mostly associated with the

Correspondence to: Aguinaldo Nepomuceno Marques Junior E-mail: aguinaldonepomuceno@id.uff.br burning of fossil fuels and industrial activities. These sources emit a great variety of pollutants into the atmosphere, among which stand out particulate matter, nitrogen and sulfur gases, ozone and metallic compounds (Marquita 2010). The particulate matter 
accumulates most of the metallic elements emitted into the atmosphere, such that there is a direct relationship between the concentrations of these two components (Kandlikar and Ramachandran 2000). The fine fraction of the particulate matter (PM2.5-10) is the most striking, because it has a longer residence time in the atmosphere ( $\sim 10$ days $)$ and can be transported over considerable distances (Minami et al. 1990, Van Valin et al. 1981).

Lead $(\mathrm{Pb})$ is the trace metal with the highest emission rates for the atmospheric environment of urban areas (Marquita 2010). High lead concentrations are frequently reported in aerosols sampled at these areas. Its impact in the environment, as well as for the human health, has been the target of several studies in the last decades (Alloway and Ayres 1997, Harrison and Laxen 1981, Manahan 2000). However, based only on measurements of $\mathrm{Pb}$ concentration, it is not frequently possible to determine the cause of its high content or to distinguish between natural and anthropogenic sources and among multiple origins from specific $\mathrm{Pb}$ end-members. The results of these studies have shown that stable lead isotopes $\left({ }^{204} \mathrm{~Pb}\right.$, ${ }^{206} \mathrm{~Pb},{ }^{207} \mathrm{~Pb}$ and ${ }^{208} \mathrm{~Pb}$ ) can be successfully used for elucidating sources of air pollution and for tracing the influence of urban and industrial pollution plumes in surrounding areas.

Lead has four main isotopes present in the environment: ${ }^{208} \mathrm{~Pb}(52 \%),{ }^{206} \mathrm{~Pb}(24 \%),{ }^{207} \mathrm{~Pb}(23 \%)$ and ${ }^{204} \mathrm{~Pb}(1 \%)$. The radiogenic isotopes ${ }^{206} \mathrm{~Pb},{ }^{207} \mathrm{~Pb}$ and ${ }^{208} \mathrm{~Pb}$ are products of radioactive decay from the natural series of ${ }^{238} \mathrm{U},{ }^{235} \mathrm{U}$ and ${ }^{232} \mathrm{Th}$, respectively. Otherwise, ${ }^{204} \mathrm{~Pb}$ is the only primordial lead stable isotope with a fixed abundance on Earth, while the abundance of radiogenic isotopes in a sample depends strictly on the concentrations of $U$ and $T h$ as well as their paths of decay, given by the half-lives $(\mathrm{t} 1 / 2)$ of the parent isotopes, besides the primordial lead content. The abundance of ${ }^{207} \mathrm{~Pb}$ has strongly changed with time compared to ${ }^{206} \mathrm{~Pb}$ because most ${ }^{235} \mathrm{U}$ has already decayed while ${ }^{238} \mathrm{U}$ still has a relatively high abundance on Earth. The isotopic composition of $\mathrm{Pb}$ is not significantly affected by physico-chemical fractionation processes; therefore, $\mathrm{Pb}$ isotopes provide an efficient tool for determining the sources and pathways of $\mathrm{Pb}$ pollution (Komárek et al. 2008).

Several studies on atmospheric pollution, as well as air quality monitoring programs, have used bioindicators. The vast majority of these studies used epiphytic organisms, such as lichens (Conti et al. 2016, Giordani 2007, Szczepaniak and Biziuk 2003, Van Dobben and Ter Braak 1999) and certain bromeliads (Alves et al. 2008, Brighigna et al. 2002, Figueiredo et al. 2007, Pyatt et al. 1999) as indicators. Such organisms uptake nutrients from the atmosphere and have the ability to accumulate well beyond their physiological needs (Godinho et al. 2009). This approach is an advantageous alternative to monitoring using pumps and filters, due to its low cost, its efficiency to monitor wide geographical areas for long periods of time, and the possibility to evaluate metallic elements that accumulate in the environment (Fuga 2006, Fuga et al. 2008).

The present study aims to evaluate lichen Parmotrema crinitum (Ach.) and bromeliad Tillandsia usneoides (L.) (also named "elder beard") as indicators of atmospheric pollution by metallic elements in the metropolitan region of Rio de Janeiro and its surroundings, a metropolis with 12 million inhabitants. For this purpose, the concentrations of $\mathrm{Na}, \mathrm{K}, \mathrm{Al}, \mathrm{Mn}, \mathrm{Pb}, \mathrm{Ni}$ and $\mathrm{Cr}$ and the lead stable isotopic composition $\left({ }^{206} \mathrm{~Pb} /{ }^{207} \mathrm{~Pb}\right.$ and ${ }^{208} \mathrm{~Pb} /{ }^{206} \mathrm{~Pb}$ ) were determined in epiphytes sampled in different areas at various distances from the city of Rio de Janeiro. The results were also compared to metallic contents of rocks from each area.

\section{MATERIALS AND METHODS}

\section{SITE DESCRIPTION}

The study was undertaken near the shore region of Rio de Janeiro City (Brazil) and in inner 
areas surrounding the metropolitan region at the municipalities of Guapimirim, Teresópolis and Nova Friburgo. These last are located in the "Serra do Mar" mountain, northward from the city (Figure 1). The Rio de Janeiro metropolitan area (RJMA) is the second country's largest urban agglomeration, with 12 million inhabitants (IBGE 2011). The area has the second largest industrial park of the country, which includes metallurgic, shipping yards, petrochemical, gas-chemical, textile, printing, pharmaceutical industries, and oil refineries (FEEMA 1979, 2004). The hydrocarbon atmospheric levels of the RJMA decreased in the last years (Massone et al. 2015) and air quality parameters range from normal to above the limits according to Brazilian legislation (CONAMA 1990). The Municipality of Guapimirim, with 57,000 inhabitants, located $50 \mathrm{~km}$ from the center of the city of Rio de Janeiro, has large preserved forest areas. Likewise, Teresópolis and Nova Friburgo are in not overpopulated region (respectively 174,000 and 185,000 inhabitants), located at $\sim 1000 \mathrm{~m}$ above sea level, about $170 \mathrm{~km}$ from Rio de Janeiro downtown (IBGE 2011).

The climate of the region varies from tropical semi-humid, with dry winters and abundant rainfall in the summer. Annual average temperatures are 22-24 ${ }^{\circ} \mathrm{C}$ in the lowland till meso-thermic mild super-humid according Köppen classification (Alvares et al. 2013) with mild summers and annual



Figure 1 - Map of the Central and North Region of Rio de Janeiro State, showing the geological and topographical setting of the study area and the sampling sites of epiphytes (circle). Geological information: 1. Cenozoic deposits, 2. KT igneous alkaline rocks, 3. biotite granites (510-480 $\mathrm{Ma})$, 4. Granites (560 Ma), 5. leucogranites and charnockites (590-560 Ma), 6. Rio Negro magmatic arc and related suites (790-620 Ma), 7. Paraíba do Sul complex, 8. paragneisses, 9. orthogneisses, amphibolites and paragneisses, 10. Faults, 11. Rio de Janeiro Metropolitan Area (RJMA), 12.Topographic profile throughoutthesampling sites. Modified from Monna et al. (2017). 
averages of $13-23{ }^{\circ} \mathrm{C}$ in the hill region. Rainfall varies between 1,500 and 2,000 mm, but levels of up to $3,600 \mathrm{~mm}$ are observed with some frequency in some mountainous areas (Castro 2008, FIDERJ 1978).

The topography of the region presents great contrasts and is composed to the south by coastal plains, and to the north by mountains with $2000 \mathrm{~m}$ of altitude, which extend up to $60 \mathrm{~km}$ distance from the coast ("Serra do Mar"). This mountainous region is parallel to the coastline and forms part of the Ribeira Belt, a Neoproterozoic to Cambrian orogenic belt of West Gondwana. This crystalline complex is composed by granitic and metamorphic rocks and lies $1400 \mathrm{~km}$ along the Atlantic coast of Brazil in a NE-trend (Almeida et al. 1981, Hasui et al. 1975, Heilbron et al. 2004, Trouw et al. 2000). The study area outcrop rocks are mainly Neoproterozoic paragnaisses (mainly silimanate-biotite-gnaisse) and ortognaisses, and by Neoproterozoic, Ordovician and Cambrian granites. We present below the mainly features of the sampling locations.

Rio de Janeiro Botanical Garden (RJ) - This site is a park and research center founded by The King of Portugal, Brazil and Algarve during the $19^{\text {th }}$ century. Today, $\boldsymbol{R} \boldsymbol{J}$ is an urban area of Rio de Janeiro municipality, located $5 \mathrm{~km}$ away from the sea.

Guapimirim (GP) and Teresópolis (TR) - The $\boldsymbol{G P}$ and $\boldsymbol{T R}$ sampling sites are located at 50 and 60 $\mathrm{km}$ far from downtown, in areas belonging to The "Serra dos Órgãos" National Park (PARNASO). This park covers approximately 20 thousand hectares. It presents a strongly mountainous relief without flat surfaces, and its vegetation is predominantly composed by extensive areas of dense ombrophyllous forest. The $\boldsymbol{G P}$ and the $\boldsymbol{T} \boldsymbol{R}$ sites are close to each other, but exhibit important difference in elevation: $600 \mathrm{~m}$ and $1200 \mathrm{~m}$ above sea level, respectively. The climate of this region is super-humid subtropical. The bromeliad $T$. usneoides was not found in these sites.
Lumiar $(\boldsymbol{L} \boldsymbol{U})$ - This site is mainly occupied by small farms and located $100 \mathrm{~km}$ far from Rio de Janeiro downtown, in the region of Lumiar, municipality of Nova Friburgo. Besides the rural area, there are preserved forest patches ("Área de Proteção Ambiental de Macaé de Cima"). The protected area is composed of ombrophyllous hill dense forest in humid subtropical climate, with approximately 7 thousand hectares of, and is located at 1,100 $\mathrm{m}$ above sea level (a.s.1.).

\section{SAMPLING AND ANALYTICAL METHODS}

Sampling of epiphyte Parmotrema crinitum (PAR) lichens and Tillandsia usneoides (TIL) bromeliads was performed at trees in four sites comprising urban, rural and national park forest areas during April 2011. At all sites, about 12-15 individual talli of $P$. crinitum (Ach.) were sampled. Moreover, 14-15 samples of the bromeliad T. usneoides ("elder beard") were also collected at the rural and urban sites. The samples were collected with plastic gloves and inert material from trunks and/ or branches of living trees at a height ranging from one to three meters of the ground in a circle with $10 \mathrm{~m}$ of radius. The samples were stored in plastic bags and impurities such as bark of trees and any residues were removed manually in laboratory. The samples were then washed with Milli-Q water in an ultrasonic bath for 1 minute to remove dust and any remaining debris from the leaf (Getty et al. 1999). After this step, the samples were oven dried $\left(45^{\circ} \mathrm{C}\right.$ until constant weight) and hand grinded in agate mortar to obtain a fine and homogeneous powder.

\section{METALLIC ELEMENT ANALYSIS}

The metallic elements $\mathrm{Na}, \mathrm{K}, \mathrm{Al}, \mathrm{Mn}, \mathrm{Pb}, \mathrm{Ni}$ and $\mathrm{Cr}$ were determined after total digestion of $60-100 \mathrm{mg}$ of samples with a $2 \mathrm{ml}$ mixture each of concentrated supra pure acids (Merck): $\mathrm{HNO}_{3}, \mathrm{HCl}$ and $\mathrm{HF}$ $(1: 1: 1)$ on hot plate. The solutions were evaporated 
and retaken with $\mathrm{HNO}_{3}$, and appropriately diluted with Milli-Q water.

The analytical determinations of the elements were performed with an ARCOS ICP-AES. Blanks $(n=8)$ and certified reference material (processed intermittently with epiphyte samples): Leaves of peach (NIST-1547); Estuarine sediment (BCSS-1), Basalt (BCR-2); Freshwater (SLRS-4 and SLRS5). Blank concentrations appeared always to be in the baseline and the values obtained for reference material never exceeded $10-15 \%$ range of their nominal concentrations. All results were based in five runs.

The metallic element data from rocks of each region were obtained from reports of Geological Survey of Rio de Janeiro State (CPRM 2012), and also from personal communication with local geologists.

\section{LEAD STABLE ISOTOPE ANALYSIS}

The following isotopic ratios were determined in epiphyte stems: ${ }^{206} \mathrm{~Pb} /{ }^{207} \mathrm{~Pb}$ and ${ }^{208} \mathrm{~Pb} /{ }^{206} \mathrm{~Pb}$. About $100 \mathrm{mg}$ samples, previously dried and grinded, were digested in Teflon beakers with $6 \mathrm{ml}$ mixture (1:1:1) of concentrated supra pure $\mathrm{HNO}_{3}: \mathrm{HCl}: \mathrm{HF}$ (Merck) on hot plate. Lead isotopic compositions $\left({ }^{206} \mathrm{~Pb} /{ }^{207} \mathrm{~Pb}\right.$ and ${ }^{208} \mathrm{~Pb} /{ }^{206} \mathrm{~Pb}$ ratios $)$ were measured with a high resolution-inductively coupled plasma mass spectrometer (HR-ICP-MS) Element 2. Instrumental mass bias was corrected by samplestandard bracketing techniques, using a NBS 981 solution as the bracketing standard (Monna et al. 1998, 2000). The analytical precision up to the third decimal place are typically of $2-3$ for ${ }^{206} \mathrm{~Pb} /{ }^{207} \mathrm{~Pb}$ and $4-7$ for ${ }^{208} \mathrm{~Pb} /{ }^{206} \mathrm{~Pb}$ ratios (at a $95 \%$ confidence level). Lead blanks were determined for each eight epiphyte samples. They were low so that sample results did not require any correction.

More details about standard procedures, settings, blanks, analytical precision and detection limits can be found in (Monna et al. 1998, 2006).

\section{STATISTICAL ANALYSIS}

Descriptive statistics (mean and range) were determined for metallic elements and stable lead isotope ratios. Nonparametric tests were applied when the assumptions of parametric tests could not be met with either the non-transformed or transformed data.

A Kruskal-Wallis (KW) test was performed to determine the significant differences among the likens sampled in four sites ( $\boldsymbol{R} \boldsymbol{J}$ - Botanical Garden of Rio de Janeiro City; $\boldsymbol{G P}$ - Serra dos Órgãos National Park-Guapimirim; TR - Serra dos Órgãos National Park - Teresópolis and $\boldsymbol{L} \boldsymbol{U}$ - Lumiar). Dunn's nonparametric comparison was used as post hoc KW testing. T-test was used for bromeliads sampled in two sites ( $\boldsymbol{R} \boldsymbol{J}$ and $\boldsymbol{L} \boldsymbol{U})$. Correlations among the parameters (metal concentrations and isotope ratios of stable isotopes of $\mathrm{Pb}$ ) were examined through Spearman Correlation Analysis and Principal Component Analysis (PCA). The data were transformed using $\log (\mathrm{x}+1)$ or cubic root in order to get normal distribution (Zar 1984). All statistical tests were performed with the program PAST, version 2.17b (Hammer et al. 2001).

\section{RESULTS}

\section{METALLIC ELEMENTS IN EPIPHYTES AND} GEOLOGICAL SETTLEMENTS

Metal concentrations in the lichen Parmotrema crinitum $(\boldsymbol{P A R})$ and the bromeliad Tillandsia usneoides (TIL), as well as in the rocks (outcrop) from the different sampling areas are presented in Table I and box plots of Figure 2. Sodium, aluminum, manganese, chrome and nickel concentrations were lower in both $\boldsymbol{P A R}$ and $\boldsymbol{T I L}$ than rocks. Significant variations were observed for $\mathrm{Na}, \mathrm{Al}$ and $\mathrm{Cr}$ in Parmotrema crinitum between Botanical Garden $(\boldsymbol{R} \boldsymbol{J})$ and mountain sites $(\boldsymbol{G P}$ and $\boldsymbol{T R}$ ) (Kruskal-Wallis; $\mathrm{p}<0.05$ ). Otherwise, potassium concentrations in the epiphytes and 


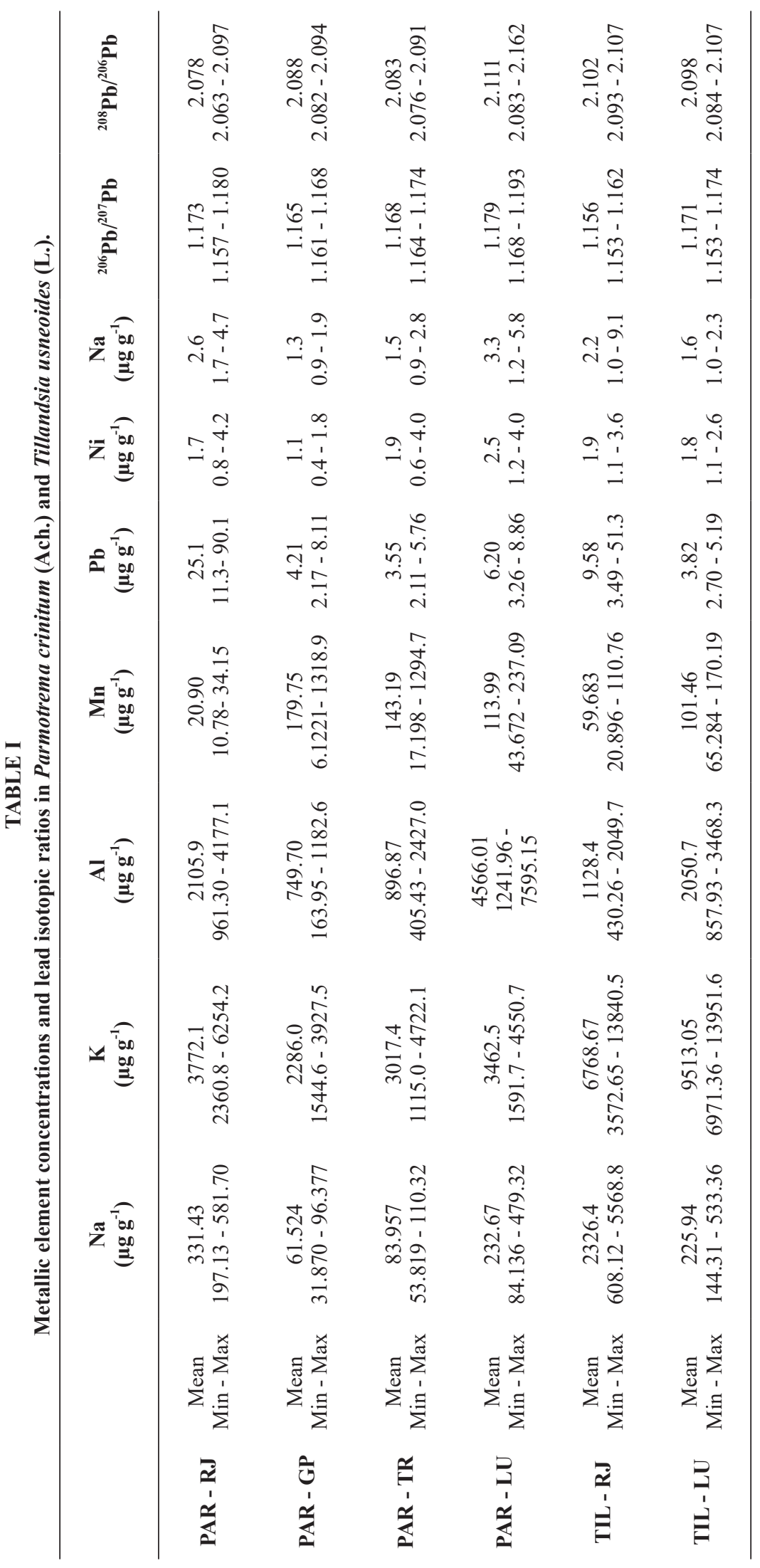



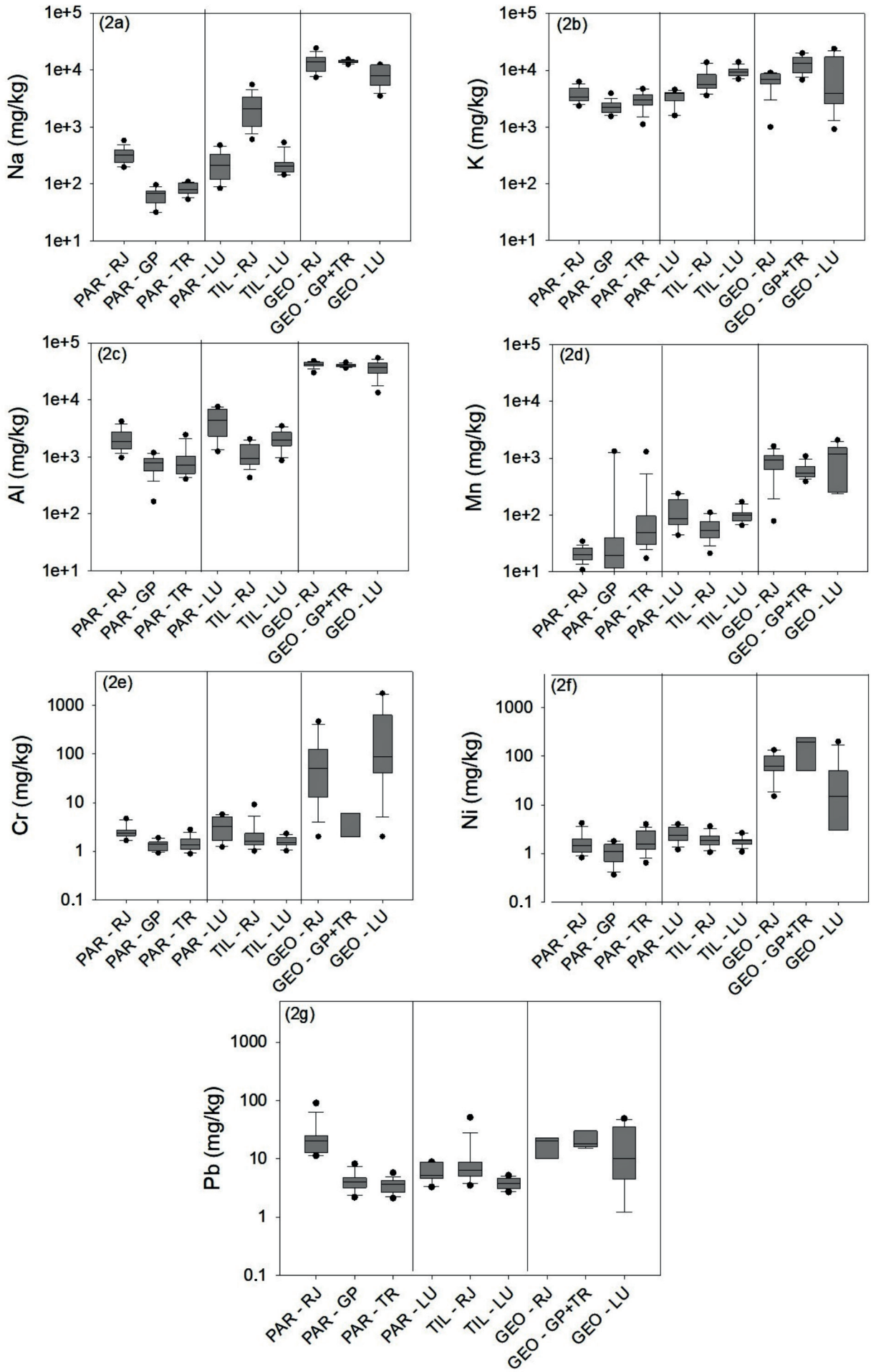

Figure 2 - "Boxplot" of metallic element concentrations (Na, K, Al, Mn, Cr, Ni and Pb) in Parmotrema crinitum (Ach.), Tillandsia usneoides (L.) and rocks from sampling area in Rio de Janeiro State. 
rocks were in the same order of magnitude for all study sites. Finally, lead concentrations were highest in likens from the urban site $(\boldsymbol{R} \boldsymbol{J})$.

The most remarkable feature of $\mathrm{Na}$ in epiphytes was the reduction of concentrations with the shore distance $(\boldsymbol{R} \boldsymbol{J}>\boldsymbol{L} \boldsymbol{U}>\boldsymbol{G P} \sim \boldsymbol{T R})$. The sodium concentrations were respectively 5 and 10 times higher in the epiphytes of the Rio de Janeiro sampling site $(\boldsymbol{R} \boldsymbol{J})$ than in those of the PARNASO forest and Nova Friburgo sites $(\boldsymbol{G P}, \boldsymbol{T R}$ and $\boldsymbol{L} \boldsymbol{U}$, respectively). The sodium concentrations in rock outcrops of the city of Rio de Janeiro and PARNASO were similar and their averages were approximately twice as high as in the Lumiar region (Figure 2). The epiphytes did not show spatial patterns in concentration for $\mathrm{Al}, \mathrm{Cr}$ and $\mathrm{Ni}$. However, chrome and nickel concentrations in rocks were: $\boldsymbol{G P} \sim \boldsymbol{T R}>\boldsymbol{R} \boldsymbol{J}>\boldsymbol{L} \boldsymbol{U}$.

The average concentrations of metallic elements in the two species and in the rocks of each site $(\boldsymbol{R J} ; \boldsymbol{G P} ; \boldsymbol{T R} ; \boldsymbol{L} \boldsymbol{U})$ were normalized by each $\mathrm{Al}$ average. These ratios ([Met] / [Al]) are presented in the Figure 3 for both species of each sampling site. Sodium and nickel concentrations in epiphytes were similar of those of the respective rocks of geological basement (Figure 2a, f). The exception to this pattern was $T$. usneoides from the urban area $(\boldsymbol{R J})$, which presented the average [Na] / [Al] ratio higher than that of the local geology (Figure 3a). The $[\mathrm{Mn}] /[\mathrm{Al}]$ ratios in the epiphytes and rocks of Rio de Janeiro $(\boldsymbol{R} \boldsymbol{J})$ and Nova Friburgo $(\boldsymbol{L} \boldsymbol{U})$ were similar (Figure 3c). This pattern was also observed for the $[\mathrm{Cr}] /[\mathrm{Al}]$ ratios at the urban area sampling site $(\boldsymbol{R} \boldsymbol{J})$. Otherwise, these ratios for P. Crinitum in PARNASO sites (GP, TR) were approximately twice than the average values for local geology (Figure 3e)

The concentration ratios $[\mathrm{Pb}] /[\mathrm{Al}]$ were always higher in the epiphytes than in the rocks in the three areas $(\boldsymbol{R} \boldsymbol{J}, \boldsymbol{T R}, \boldsymbol{L} \boldsymbol{U})$ (Figure 3f). A second pattern observed for the $\mathrm{Pb}$ was the decrease of the ratios in both species gradually from the metropolitan region toward the countryside of Rio de Janeiro State. The $[\mathrm{Pb}] /[\mathrm{Al}]$ ratios for plants indicate a spatial gradient of concentrations as follows: $\boldsymbol{R J}>\boldsymbol{G P}-\boldsymbol{T R}>\boldsymbol{L} \boldsymbol{U}$.

\section{STABLE LEAD ISOTOPE RATIOS IN EPIPHYTES}

The lead isotope ratios $\left({ }^{206} \mathrm{~Pb} /{ }^{207} \mathrm{~Pb}\right.$ and $\left.{ }^{208} \mathrm{~Pb} /{ }^{206} \mathrm{~Pb}\right)$ of epiphytes are presented in Table I and compared with sediments of Guanabara Bay $(\boldsymbol{B} \boldsymbol{G})$, one of the main polluted coastal environments, which is located in the study area (Figures 1 and 4). As mentioned earlier, $P$. critinum collected in the four sites $(\boldsymbol{R J}, \boldsymbol{G P}, \boldsymbol{T R}, \boldsymbol{L U})$ and T. usneoides in two $(\boldsymbol{R J}, \boldsymbol{L} \boldsymbol{U})$.

The ${ }^{208} \mathrm{~Pb} /{ }^{206} \mathrm{~Pb}$ ratios had smaller range in Tillandsia usneoides than in Parmotrema crinitum, varying from 2.084 to 2.107 in the bromeliad and between 2.063 and 2.162 in the lichen (Table I, Figure $4 a, b)$. On the other hand, the distribution of the isotopic ratios of the epiphytes allows distinguishing two groups based on the location of the sampling area. The first group consists of samples that define an axis of atmospheric dispersion in the direction of Rio de Janeiro-GuapimirimTeresópolis $(\boldsymbol{R} \boldsymbol{J}, \boldsymbol{G P}, \boldsymbol{T R})$. The second one by the samples from Nova Friburgo $(\boldsymbol{L} \boldsymbol{U})$, where there are the major extension of the farmlands of Rio de Janeiro State. The plot ${ }^{208} \mathrm{~Pb} /{ }^{206} \mathrm{~Pb}$ vs ${ }^{206} \mathrm{~Pb} /{ }^{207} \mathrm{~Pb}$ for the epiphytes (Figure 4 ) showed that the $1^{\text {st }}$ group (atmospheric dispersion) is linearly related, especially in the case of Parmotrema crinitum, while the $2^{\text {nd }}$ group (farmlands) is quite scattered.

\section{DISCUSSION}

Metal concentrations in epiphytes of the different studied areas showed distinguished patterns, which are related with the distance from the urban area, distance from the shore, elevation above sea level (a.s.1.) and geochemical composition of rocks in each region $(\boldsymbol{R} \boldsymbol{J}-$ densely populated area at sea level; $\boldsymbol{G P}$ - Ombrophyllous Forest at 600 m a.s.1; 

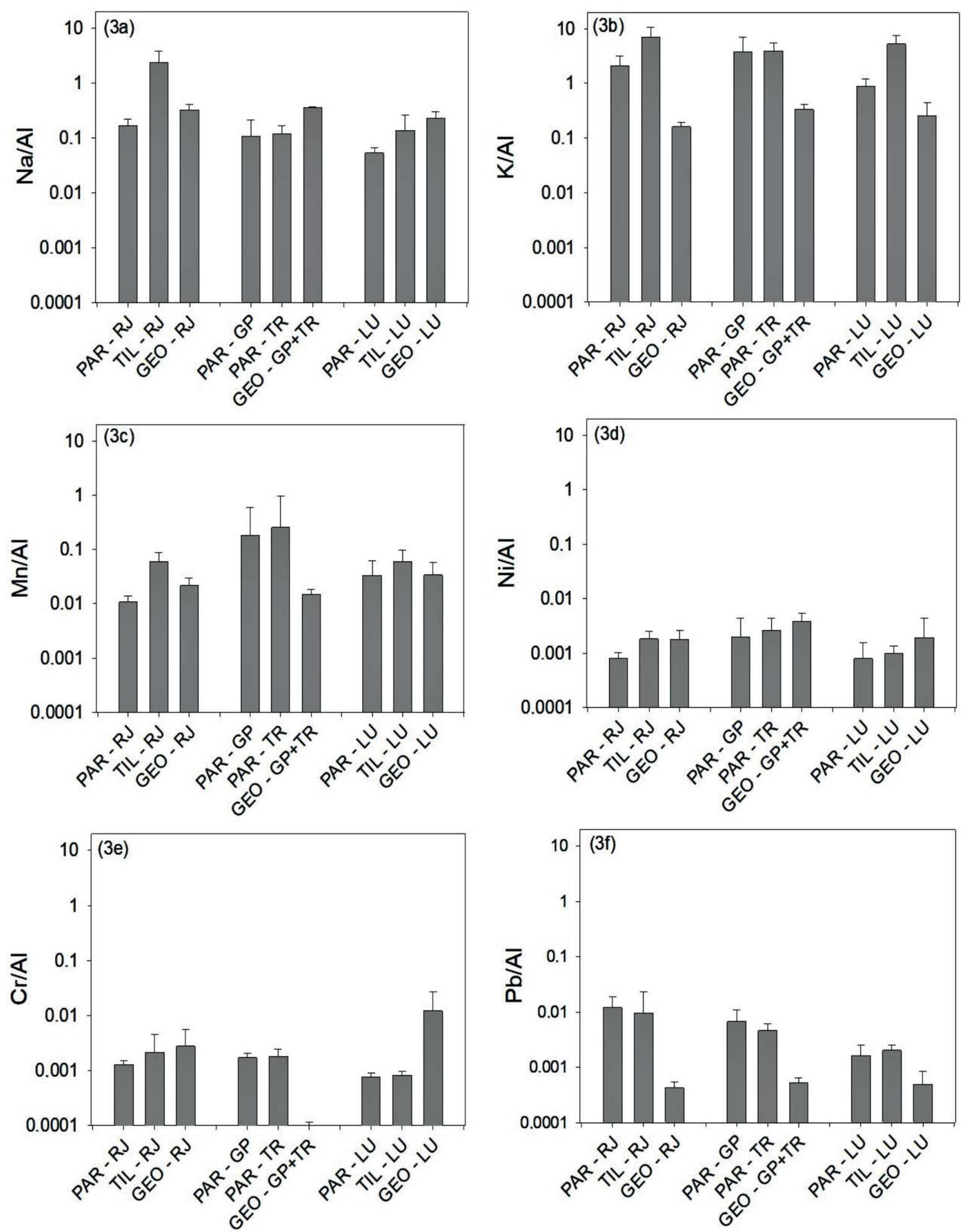

Figure 3 - Histogram of metallic elements ( $\mathrm{Na}, \mathrm{K}, \mathrm{Mn}, \mathrm{Cr}, \mathrm{Ni}$ and $\mathrm{Pb}$ ) normalized by $\mathrm{Al}$ for Parmotrema crinitum (Ach.), Tillandsia usneoides (L.) and rocks from sampling area in Rio de Janeiro State. 

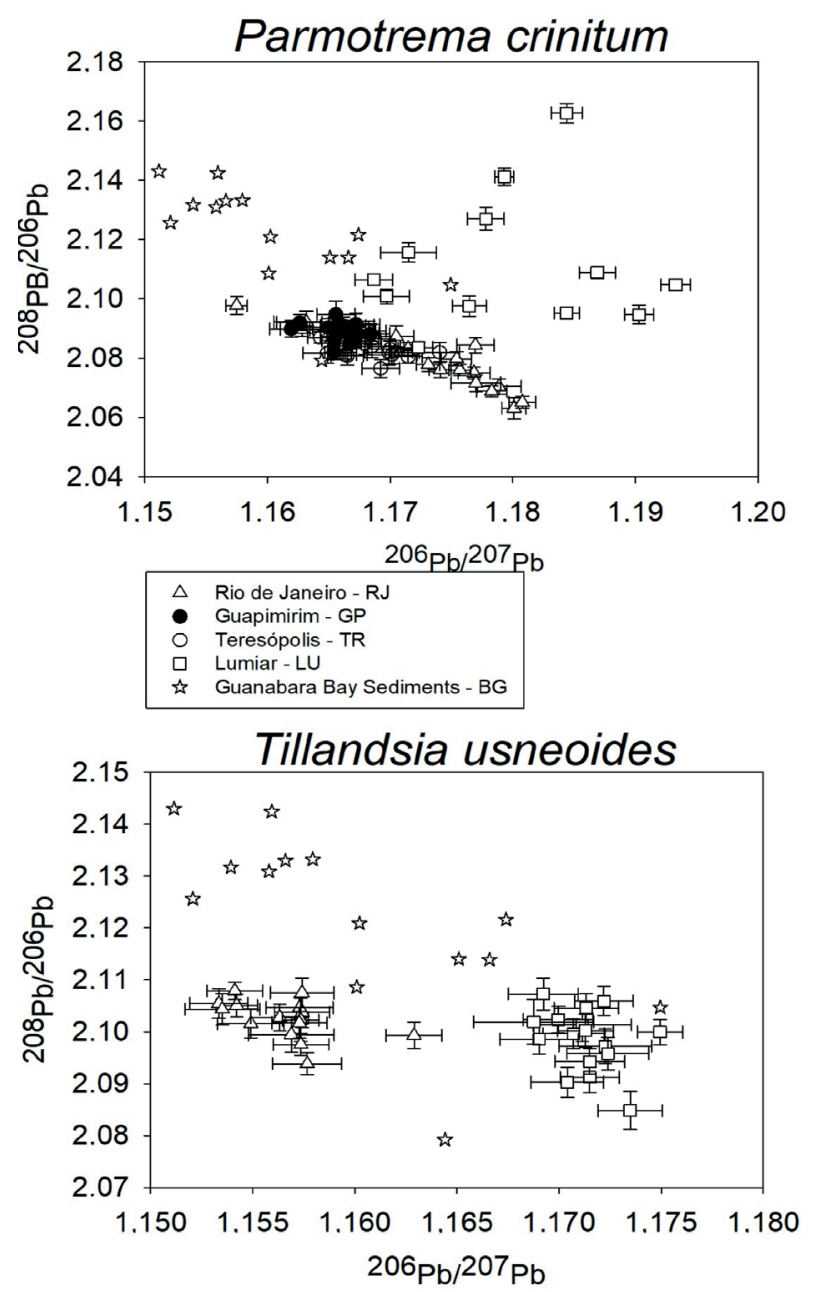

Figure 4 - Plot of lead isotope ratios $\left({ }^{206} \mathrm{~Pb} /{ }^{207} \mathrm{~Pb}\right.$ vs. $\left.{ }^{208} \mathrm{~Pb} /{ }^{206} \mathrm{~Pb}\right)$ for Parmotrema crinitum (Ach.) and Tillandsia usneoides (L.). Guanabara Bay sediments (BG).

$\boldsymbol{T R}$ - Pristine Ombrophyllous Forest at $1200 \mathrm{~m}$ a.s.1; $\boldsymbol{L} \boldsymbol{U}$ - Farmlands with low demography at 900 $\mathrm{m}$ a.s.1.).

Studies comparing metal concentrations in epiphytes organisms with background levels, as local rocks, are lacking, and no work of such kind was known in Brazil. The average concentrations of $\mathrm{Na}, \mathrm{Al}, \mathrm{Mn}, \mathrm{Cr}, \mathrm{Ni}$ and $\mathrm{Pb}$ measured in the epiphytes in this study tended to be lower than those of the local rocks, while they were in the same order of magnitude as those reported for other bioindicators in Brazil (Figueiredo et al. 2004), South America (Abril et al. 2014) and European countries (Agnan et al. 2015, Basile et al. 2008, Jeran et al. 2002, Loppi and Pirintsosb 2003).

The potassium appears as an exception, since it was more enriched in epiphytes than the geological settings (Figure 1b). Nevertheless, potassium concentrations were in the same order of magnitude as those reported in other studies for epiphytes in Brazilian urban centers and in other countries (Figueiredo et al. 2004, 2007, Jeran et al. 2002). The potassium excess is highlighted by the $[\mathrm{K}] /[\mathrm{Al}]$ ratios, which are always greater than 1 in the epiphytes $\left(\mathrm{K}_{\text {epi }} / \mathrm{Al}_{\text {epi }}>1\right)$ (Figure $\left.2 \mathrm{~b}\right)$. Potassium is a macronutrient essential for plant development, included epiphytes, and its uptake may not be exclusively by the atmospheric source, but indeed assimilated through the leaching of the foliage of the trees (Läuchli and Pflüger 1978). Thus, the observed behavior of $\mathrm{K}$ can be related with epiphyte metabolic activity produced by the K-Na pump, which is the mechanism leading the cells to sucking essential $\mathrm{K}$, while discarding reactive $\mathrm{Na}$. Besides, potassium is highly soluble and tends to be replaced in minerals being leached from weathered rocks.

Sodium and lead also distinguished by particular behaviors in epiphytes. The first by its high concentrations in epiphytes of the urban site $(\boldsymbol{R} \boldsymbol{J})$, particularly in T. usneoides. This species showed $\mathrm{Na}$ concentrations higher than P. crinitumin Botanical Garden, as well as around five times higher than the epiphytes of the other sampling sites. The affinity of T. usneoides for $\mathrm{Na}$ can be attributed to anatomical particularities (Koz et al. 2010), but relatively high concentrations of $\mathrm{Na}$ have also been reported for epiphytes in the metropolitan region of São Paulo, the largest Brazilian city (Figueiredo et al. 2007). In this study, the presence of a spatial gradient in Na concentrations was described as follows: Rio de Janeiro $(\boldsymbol{R} \boldsymbol{J})>$ Guapimirim $(\boldsymbol{G P})>$ Teresópolis $(\boldsymbol{T R})$ $>$ Nova Friburgo $(\boldsymbol{L U})$. This pattern is explained by the fact that the Botanical Garden $(\boldsymbol{R} \boldsymbol{J})$ is located in the coastal area of the city of Rio de Janeiro, 
therefore under strong influence of the marine salt spray. In the other hand, the high $\mathrm{Na}$ concentration in bromeliad T. usneoides suggests that it would be a better indicator to trace de marine spray than $P$. crinitum.

Similar to the $\mathrm{Na}$ behavior, $\mathrm{Pb}$ also presented its highest concentrations in the epiphytes collected in the urban region $(\boldsymbol{R} \boldsymbol{J})$. However, unlike the $\mathrm{Na}$ case, the concentrations of atmospheric $\mathrm{Pb}$ appear to be best mimicked by the lichen Parmotrema crinitum. Thus, in the urban area, this species presented the highest concentrations of $\mathrm{Pb}$ of the whole study, which were even similar to those of the rocks (Figures 2 and 3). A recent study about air quality in the same region using perturbation vectors, observed singular behavior for $\mathrm{Pb}$ in the two epiphytes (Monna et al. 2017) as occurred in the present study. High lead levels may be related with anthropogenic sources, as fuel burning, industrial processes and solid waste incineration, as recognized for some other urban areas in the world (Komárek et al. 2008, Monna et al. 2006).
This is reinforced by the fact that the relatively high concentrations in epiphytes of the urban site, the Botanical Garden $(\boldsymbol{R} \boldsymbol{J})$ are similar to those of other urban areas in Brazil and the world as well (Abril et al. 2014, Agnan et al. 2015, Basille et al. 2008, Figueiredo et al. 2007, Jeran et al. 2002, Käffer et al. 2012, Loppi and Pirintsosb 2003). In addition, $\mathrm{Na}$ and $\mathrm{Pb}$ stood out together with the isotopic ratio ${ }^{206} \mathrm{~Pb} /{ }^{207} \mathrm{~Pb}$, forming a group on the second axis of the principal component analysis (PCA) performed for $P$. crinitum (Figure 5). In Brazil, the use of $\mathrm{Pb}$ as an additive for gasoline was interrupted in 1986. However, residual $\mathrm{Pb}$ levels still remaining in the environment may have as main source the vehicle emissions (Fernández 2004). The ${ }^{206} \mathrm{~Pb} /{ }^{207} \mathrm{~Pb}$ ratio values obtained for both epiphytes in the urban site $(\boldsymbol{R J})$ were similar to those reported for gasoline in Brazilian cities such as São Paulo (Migliavacca et al. 2012). The observed pattern for the aerosol of this city is that the highest concentrations of $\mathrm{Pb}$ in the atmosphere coincide with large fireworks



Figure 5 - PCA plot for metallic elements and isotope ratios of Parmotrema crinitum (Ach.) from four sampling sites in Rio de Janeiro State. 
during celebration events and associated with high traffic occurrence (Gioia et al. 2010).

The distribution patterns of $\mathrm{Na}, \mathrm{Pb}$ and ${ }^{206} \mathrm{~Pb} /{ }^{207} \mathrm{~Pb}$ ratios in Rio de Janeiro are likely driven by the wind regime. This suggests that the drivers of $\mathrm{Pb}$ dispersion should be related with circulation of major air masses by convection from polluted areas into the atmospheric boundary layer. In other words, frequent cold fronts in the region would transport air masses from the metropolitan region of the city of Rio de Janeiro towards the mountainous region of Teresópolis. These mountains, located approximately $60 \mathrm{~km}$ to the north, could act as a barrier to the moisture in these air masses, causing frequent orographic rainfall. Since the region of Nova Friburgo is located at the east side of the National Park (PARNASO) and far from the Rio de Janeiro downtown, it would be less affected by this system of atmospheric dispersion.

In contrast, the observed correlations between $\mathrm{K}$, Ni and the ${ }^{208} \mathrm{~Pb} /{ }^{206} \mathrm{~Pb}$ ratio, responsible for the greater part of explanation of the PCA first axis seemed to be related to other factors. The potassium is assumed to be related to nutritional aspects, while the others ( $\mathrm{Ni}$ and ${ }^{208} \mathrm{~Pb} /{ }^{206} \mathrm{~Pb}$ ratio) are supposed as fingerprints of local geology. High ${ }^{208} \mathrm{~Pb}$ levels of epiphytes in Lumiar (Figure 4) suggest influence of monazite fluvial deposits that occurs in several places of the "Serra do Mar"(Overstreet 1967) as can be seen from samples 50 to 62 and ${ }^{208} \mathrm{~Pb} /{ }^{206} \mathrm{~Pb}$ vector (Figure 5). This could indicate a contribution of metals from rocks to epiphytes through aerosol deposition.

Positive correlations between chemical elements may indicate that they come from the same source (Hoff Brait and Filho 2010). For instance, one source related to atmospheric pollution could be represented by the correlation between $\mathrm{Pb}$ concentrations and the ${ }^{206} \mathrm{~Pb} /{ }^{207} \mathrm{~Pb}$ ratio in the epiphytes from the urban area $(\mathrm{R}=0.592$; $\mathrm{p}<0.05$ ). Thus, it is evident that the first axis of the PCA plot is described by a natural (geological and/or nutritional) factor, while the second axis is associated with the anthropogenic factors. A study carried out in the Belém City metropolitan area (north Brazil) also clearly distinguished between natural $\mathrm{Pb}$ from lithosphere, and that derived from anthropogenic contribution, using the ${ }^{206} \mathrm{~Pb} /{ }^{207} \mathrm{~Pb}$ ratios. In the first case, the value of the ${ }^{206} \mathrm{~Pb} /{ }^{207} \mathrm{~Pb}$ ratio was around 1.20 , whereas the anthropogenic $\mathrm{Pb}$ would have a ${ }^{206} \mathrm{~Pb} /{ }^{207} \mathrm{~Pb}$ ratio of equal or less than 1.15 (Moura et al. 2004). These values are comparable with those obtained in the epiphytes of this study.

\section{CONCLUSIONS}

Among all the metallic elements analyzed, the $\mathrm{K}$ was the only whose the concentrations in epiphytes were similar to those of the rocks of the local geological basement. All other elements presented higher concentrations in the rocks. Such an excess of $\mathrm{K}$ is attributed to its essentiality, as a macronutrient, for epiphytes development. The sodium, aluminum, manganese, chrome, nickel and lead concentrations in epiphytes were of the same order of magnitude of those reported in other studies conducted in Brazil, South America and European countries. Sodium and lead constituted a particular and differentiated group, distinct to the other elements. The first showed high affinity for the bromeliad Tillandsia usneoides, the second one for the Parmotrema crinitum and both of them presented their highest concentrations in the downtown Rio de Janeiro Botanical Garden. The concentrations of $\mathrm{Na}$ in the plants of the Botanical Garden were 5 times higher than those of the epiphytes from the other sites. That is attributed to the influence of the salt marine spray. The second aspect related to $\mathrm{Na}$ and $\mathrm{Pb}$ was the existence of a spatial concentration gradient (Rio de Janeiro $>>$ Nova Friburgo $>$ Guapimirim $\sim$ Teresópolis). This pattern is attributed to the incidence of air masses from the metropolitan area of Rio de Janeiro to the Teresópolis mountainous region through cold fronts in the south - north 
direction and subsequent orographic precipitation, which is corroborated by the ${ }^{206} \mathrm{~Pb} /{ }^{207} \mathrm{~Pb}$ ratios. The results allowed elucidating a close connection between the pollution dispersion from the urban region of Rio de Janeiro and the slopes of "Serra do Mar". Both lichen Parmotrema crinitum and bromeliad Tillandsia usneoides are suitable to be used as bioindicators to evaluate the dispersion of atmospheric pollution by metallic elements in the State of Rio de Janeiro.

\section{ACKNOWLEDGMENTS}

The authors thank Coordenação de Aperfeiçoamento de Pessoal de Nível Superior (CAPES) for the financial support, and Dr. Cecilia Cronemberg and Instituto Chico Mendes de Conservação da Biodiversidade (ICM-Bio) for logistical support. Thanks are also due to Prof. Miguel Tupinambá for the supply of rock geochemical data.

\section{REFERENCES}

ABRIL GA, WANNAZA ED, MATEOS AC, INVERNIZI R, PLÁB RR AND PIGNATA ML. 2014. Characterization of atmospheric emission sources of heavy metals and trace elements through a local-scale monitoring network using T. capillaris. Ecol Indic 40: 153-161.

AGNAN Y, SÉJALON-DELMAS N, CLAUSTRES A AND PROBST A. 2015. Investigation of spatial and temporal metal atmospheric deposition in France through lichen and moss bioaccumulation over one century. Sci Total Environ 529: 285-296.

ALLOWAY BJ AND AYRES DC. 1997. Chemical Principles of Environmental pollution. Blackie Academic and Professional CRC press, $2^{\text {nd }}$ ed., London, UK, 395 p.

ALMEIDA FFMD, HASUI Y, BRITO-NEVES BBD AND FUCK RA. 1981. Brazilian Structural Provinces: an introduction. Earth Sci Rev 17: 1-29.

ALVARES CA, STAPE JL, SENTELHAS PC, DE MORAES GONÇALVES JL AND SPAROVEK G. 2013. Köppen's climate classification map for Brazil. Meteorol Z 22: 711728.

ALVES ES, MOURA BRBS AND DOMINGOS M. 2008. Structural Analysis of Tillandsia usneoides L. Exposed to Air Pollutants in São Paulo City, Brazil. Water Air Soil Pollut 189: 61-68.
BASILE A, SORBO S, APRILE G, CONTE B AND COBIANCHI RC. 2008. Comparison of the heavy metal bioaccumulation capacity of an epiphytic moss and an epiphytic lichen. Environ Pollut 151: 401-407.

BRIGHIGNA L, PAPINI A, MOSTI S, CORNIA A, BOCCHINI P AND GALLETTI G. 2002. The use of tropical bromeliads (Tillandsia spp.) for monitoring atmospheric pollution in the town of Florence, Italy. Rev Biol Trop, p. 577-584.

CASTRO EBV. 2008. Plano de Manejo do Parque Nacional da Serra dos Órgãos. Instituto Chico Mendes de Conservação da Biodiversidade (ICMBio), Teresópolis, p. 1-90.

CONAMA - CONSELHO NACIONAL DO MEIO AMBIENTE. 1990. Resolução ${ }^{\circ} 13$, de 06 de dezembro de 1990. Estabelece o licenciamento obrigatório para as atividades que possam afetar a biota de Unidades de Conservação. Instituto Brasileiro de Meio Ambiente e Recursos Naturais Renováveis (IBAMA), Brasília, p. 245.

CONTI ME, TUDINO MB, DE LA GUARDIA M AND ARMENTA S. 2016. Lichens as Biomonitors of HeavyMetal Pollution. Comprehensive Analytical Chemistry. Elsevier 10: 117-145.

CPRM - COMPANHIA DE PESQUISA DE RECURSOS MINERAIS. 2012. Geologia e recursos minerais da folha Baía de Guanabara SF.23-Z-B-IV, Estado do Rio de Janeiro escala 1:100.000. Programa Geologia do Brasil, Belo Horizonte, $156 \mathrm{p}$.

FEEMA - FUNDAÇÃO ESTADUAL DE ENGENHARIA DO MEIO AMBIENTE. 1979. Manual do Meio Ambiente. Sistema de Licenciamento de Atividades Poluidoras (SLAP). Rio de Janeiro: Fundação Estadual de Engenharia do Meio Ambiente, 305 p.

FEEMA - FUNDAÇÃO ESTADUAL DE ENGENHARIA DO MEIO AMBIENTE. 2004. Inventário de Fontes Emissoras de Poluentes Atmosféricos da Região Metropolitana do Rio de Janeiro. Rio de Janeiro: Fundação Estadual de Engenharia do Meio Ambiente, 293 p.

FERNÁNDEZ JCT. 2004. Seletividade da clinoptilolita natural por metais tóxicos em sistemas aquosos. Universidade Federal de São Carlos, Tese de doutorado, 170 p.

FIDERJ - FUNDAÇÃO INSTITUTO DE DESENVOLVIMENTO ECONÔMICO E SOCIAL DO RIO DE JANEIRO. 1978. Indicadores Climatológicos do Estado do Rio de Janeiro. Rio de Janeiro: Fundação Instituto de Desenvolvimento Econômico e Social do Rio de Janeiro, 156 p.

FIGUEREDO AMG, ALCALÁ AL, TICIANELLI RB, DOMINGOS M AND SAIKI M. 2004. The use of Tillandsia usneoides L. as bioindicator of air pollution in São Paulo, Brazil. J Radioanal Nucl Ch 259: 59-63.

FIGUEREDO AMG, NOGUEIRA CA, SAIKI M, MILIAN FM AND DOMINGOS M. 2007. Assessment of atmospheric metallic pollution in the metropolitan region 
of São Paulo, Brazil, employing Tillandsia usneoides L. as biomonitor. Environ Pollut 145: 279-292.

FUGAA. 2006. Uso de líquens epifíticos no biomonitoramento da poluição atmosférica da Região Metropolitana de São Paulo, Universidade de São Paulo, Tese de doutorado, 127 p.

FUGA A, SAIKI M, MARCELLI M AND SALDIVA P. 2008. Atmospheric pollutants monitoring by analysis of epiphytic lichens. Environ Pollut, p. 334-340.

GETTY SR, GUTZLER DS, ASMERON Y, SHEARER CK AND FREE SJ. 1999. Chemical signals of epiphytic lichens in southwestern North America, natural versus man-madesources for airborne particulates. Atmos Environ 33: 5095-5104.

GIOIA SMCL, BABINSKI M, WEISS DJ AND KERR AAFS. 2010. Insights into the dynamics and sources of atmospheric lead and particulate matter in São Paulo, Brazil, from high temporal resolution sampling. Atmospheric Res 98: 478485.

GIORDANI P. 2007. Is the diversity of epiphytic lichens a reliable indicator of air pollution? A case study from Italy. Environ Pollut 146: 317-323.

GODINHO RM, VERBURG TG, FREITAS MC AND WOLTERBEEK HT. 2009. Accumulation of trace elements in the peripheral and central parts of two species of epiphytic lichens transplanted to a polluted site in Portugal. Environ Pollut 157: 111-163.

HAMMER O, HARPER DAT AND RYAN PD. 2001. PAST: Paleontological Statistic software package for education and data analysis. Paleontologia electronica 1: 1-9.

HARRISON RM AND LAXEN DPH. 1981. Lead pollution causes and control. London; New York, Springer Science \& Bussiness Media, $168 \mathrm{p}$.

HASUI Y, CARNEIRO CDR AND COIMBRA AM. 1975. The Ribeira folded belt. RGB 5: 257-266.

HEILBRON M, PEDROSA-SOARES AC, CAMPOS NETO M, SILVA LC, TROUW RAJ AND JANASI VC. 2004. A Província Mantiqueira. In: Mantesso-Neto V, Bartorelli A, Carneiro CDR and Brito Neves BB (Eds), O Desvendar de Um Continente: A Moderna Geologia da América do Sul e o Legado da Obra de Fernando Flávio Marques de Almeida, p. 203-234.

HOFF BRAIT CHAND FILHO NRA. 2010. Desenvolvimento e aplicação de sistema passivo de coleta de poluentes atmosféricos para monitoramento de $\mathrm{Cd}, \mathrm{Cr}, \mathrm{Pb}, \mathrm{Cu}, \mathrm{Fe}$, $\mathrm{Mn}, \mathrm{Zn}$ e particulados totais. Quim Nova, p. 7-13.

IBGE - INSTITUTO BRASILEIRO DE GEOGRAFIA E ESTATÍSTICA. 2011. Censo Demográfico 2010. Características gerais da população. Resultados da Amostra: Instituto Brasileiro de Geográfia e Estatística.

JERAN Z, IMOVIC R, BATIC F AND MAVSAR R. 2002. Lichens as integrating air pollution monitors. Environ Pollut 120: 107-113.

KÄFFER MI, LEMOS AT, APEL MA, ROCHA JV, MARTINS SMDA AND VARGAS VMF. 2012. Use of bioindicators to evaluate air quality and genotoxic compounds in an urban environment in Southern Brazil. Environ Pollut 163: 24-31.

KANDLIKAR M AND RAMACHANDRAN G. 2000. The causes and consequences of particulate air pollution in urban India: A synthesis of the science. Annu Rev Energy Env 25: 629-684.

KOMÁREK M, ETTLER V, CHRASTNÝ V AND MIHALJVIC M. 2008. Lead isotopes in environmental sciences: A review. Environ Int 34: 562-577.

KOZ B, CELIK N AND CEVIK U. 2010. Biomonitoring of heavy metals by epiphytic lichen species in Black Sea region of Turkey. Ecol Indic 10: 762-765.

LÄUCHLI A AND PFLÜGER R. 1978. Potassium transport through plant cell membranes and metabolic role of potassium in plants. Congress International Potash Institute. Potassium research review and trends. Bern: PPI, p. 111-164.

LOPPI S AND PIRINTSOS SA. 2003. Epiphytic lichens as sentinels for heavy metal pollution at forest ecosystems (central Italy). Environ Pollut 12: 327-332.

MANAHAN SE. 2000. Environmental Chemistry: Photochemical smog. Boca Raton: CRC Press LLC.

MARQUITA KH. 2010. Understanding Environmental Pollution. Cambridge University Press: The Edinburgh Building, p. 603.

MIGLIAVACCA DM, TEIXEIRA EC, GERVASONI F, CONCEIÇÃO RV AND RODRIGUEZ MTR. 2012. Metallic elements and isotope of $\mathrm{Pb}$ in wet precipitation in urban area, South America. Atmospheric Res 107: 106114.

MINAMI Y, HAYASHI K, DOKIYA Y, OHYAMA J AND FUSHIMI K. 1990. Deposition of sulfate, chloride and sodium at Japanese meteorological observatories and on the western North Pacific. Intl J Environ Anal Chem 38: 579-589.

MONNA F ET AL. 2017. Perturbation vectors to evaluate air quality using lichens and bromeliads: a Brazilian case study. Environ Monit Assess 189(11): 566 p.

MONNA F, LOIZEAU JL, THOMAS B, GUÉGUEN C, FAVARGER PY, LOSNO R AND DOMINIK J. 2000. Noise identification and sampling frequency determination for precise $\mathrm{Pb}$ isotopic measurements by quadrupolebased inductively coupled plasma mass spectrometry. Analusis 28: 750-757.

MONNA F, LOIZEAU JL, THOMAS BA, GUÉGUEN C AND FAVARGER PY. 1998. $\mathrm{Pb}$ and $\mathrm{Sr}$ isotope measurements by inductively coupled plasma-mass spectrometer: Efficient time management for precise improvement. Spectrochim Acta A 53: 1317-1333.

MONNA F, POUJOL M, LOSNO R, DOMINIK J, ANNEGARN H AND COETZEE H. 2006. Origin of atmospheric lead in Johannesburg, South Africa. Atmos Environ 40: 6554-6566. 
MOURA CAV, GAUDETTE HE, CARVALHO MC AND MORALES GP. 2004. The use of lead isotope composition as a tool to investigate the anthropogenic impacts on the enviroment in the metropolitan region of Belém (PA). Terrae 1: 16-25.

OVERSTREET WC. 1967. The geologic occurrence of monazite. Professional Paper, Washington, Library of Congress 530: $327 \mathrm{p}$.

PYATT FB, GRATTAN JP, LACY D, PYATT AJ AND SEAWARD MRD. 1999. Comparative Effectiveness of Tillandsia usneoides L. and Parmotrema praesorediosum (Nyl.) Hale as Bio-Indicators of Atmospheric Pollution in Louisiana (USA). Water Air Soil Pollut 111: 317-326.

SZCZEPANIAK K AND BIZIUK M. 2003. Aspects of the biomonitoring studies using mosses and lichens as indicators of metal pollution. Environ Res 93: 221-230.
TROUW RAJ, HEILBRON M, RIBEIRO A, PACIULLO FVP, VALERIANO CM, ALMEIDA JCH, TUPINAMBÁ M AND ANDREIS RR. 2000. The central segment of the Ribeira Belt. In: Cordani UG, Milani EJ, Thomaz Filho A and Campos DA (Eds), Tectonic Evolution of South America. Rio de Janeiro, p. 287-310.

VAN DOBBEN HF AND TER BRAAK CJF. 1999. Ranking of Epiphytic Lichen Sensitivity to Air Pollution Using Survey Data: A Comparison of Indicator Scales. Lichenol 31: 27-39.

VAN VALIN CC, PUESCHEL RF AND WELLMAN DL. 1981. Aerosol formation, transformation, and effects in Denver's emissions plume. J Geophys Res Oceans 86: 7463-7470.

ZAR JH. 1984. Biostatistical analysis. Englewood Cliffs, NJ, Prentice-Hall, p. 620. 